\title{
Stimulating the Attractiveness of PFI/PPPs Using Public Sector Guarantees
}

\begin{tabular}{|r|l|}
\hline Journal: & $\begin{array}{l}\text { World Journal of Entrepreneurship, Management and Sustainable } \\
\text { Development }\end{array}$ \\
\hline Manuscript ID & WJEMSD-05-2018-0055.R1 \\
\hline Manuscript Type: & Research Paper \\
\hline Keywords: & $\begin{array}{l}\text { UK Guarantee Scheme for Infrastructures (UKGSI), Private Finance } \\
\text { Initiatives, Public Private Partnership (PPP), Public Sector, Stakeholders }\end{array}$ \\
\hline \multicolumn{2}{|l}{} \\
\hline
\end{tabular}


4 Purpose

\section{Stimulating the Attractiveness of PFI/PPP Projects through Public Sector Guarantees.}

5 Although the UK Guarantee Scheme for Infrastructures (UKGSI) was introduced in 2012 to

6 address the huge financing gap for critical infrastructures, PFI sponsors have so far guaranteed

7 only few projects. Many stakeholders in the project finance industry have blamed this situation

8 on lack of general understanding of strategies for harnessing the benefits of government

9 guarantees. The study therefore investigates the perspectives of PFI/PPP stakeholders in the

10 UK on critical factors influencing approval for government guarantee using the UK guarantee

11 scheme for Infrastructure as a focal point.

\section{Design/methodology/approach}

Using a mixed methodology approach, the study identified 26 important criteria used in evaluating government guarantee applications through focus group discussions with PFI stakeholders. These criteria were put in questionnaire survey to 195 respondents.

\section{Findings}

Through factor analysis, five (5) critical factors determining successful government guarantee application were unravelled. These include (1) compliance with UK National Infrastructure Plan, (2) demonstration of project bankability and risk management, (3) value for money (4) proof of dependence on the guarantee and (5) certainty of planning commission's approval.

\section{Originality/value}

Results will facilitate in-depth understanding of critical factors for accessing government guarantees, while also improving the bankability of prospective PFI projects.

Keywords: UK Guarantee Scheme for Infrastructures (UKGSI), Private Finance Initiatives (PFI), Public Private Partnership (PPP), Public Sector, Stakeholders. 


\section{$27 \quad 1.0 \quad$ Background}

28 The last global financial crisis (GFC) in 2007/08 raised serious debates about risk management 29 in the banking sector (Demirag et al., 2015). Leading up to the market crash, bank funding was 30 very much accessible with significant competition for PFI/PPP projects by offering attractive 31 loan pricing and structures to sponsors (Mills, 2010). However, by the beginning of 2008, the 32 sheer enormity of financial loss suffered by project financiers, especially mono-line credit 33 insurers at the wake of crisis, led many banks out of the PFI/PPP market (Haran et al., 2013). 34 According to the 2013 report of European PPP Expertise Centre, the European PPP market had 35 plunged to its lowest level towards the end of 2012, with deals reaching financial close as low as $€ 11.7$ billion. This reduced global activity for PPP, particularly bond and senior debt finance created huge uncertainty that threatened long-term finance for many public sector infrastructures (Hampl et al, 2011). Therefore, the need for government interventions became urgent and necessary amidst growing infrastructure demands (Toms et al., 2011, Connolly and Wall, 2011).

Realising the need to encourage more private sector investments in new United Kingdom's (U.K) public infrastructures (valued at £250billion in the NIP Policy, 2011), the HM Treasury introduced an infrastructure stimulus package known as UK Guarantee Scheme for Infrastructures (UKGSI) in July 2012 (Wynne, 2015). The primary aim of the scheme was to avoid delays to private investments in viable UK infrastructures, which may have been

47 hindered by the adverse credit situation in the financial market (HM Treasury, 2014). As part of its mandate, the scheme was to provide a sovereign-backed guarantee that makes high-risk infrastructural projects within the UK bankable to lenders, while also stimulating growth within the financial market (Wynne, 2015). However, despite the laudable objectives behind the UKGSI, a recent report from the National Audit Office (NAO, 2015) revealed that many 
52 project sponsors have only been able to secure guarantee for few infrastructure projects. 53 According to National Audit Office (2015 .p5), out of the 200 applications for government 54 guarantee scheme received by the Treasury Department, only 7 projects have been approved 55 while 39 other projects were pre-qualified.

57 From the perspectives of the HM Treasury (2013), notable among the factors militating against 58 project sponsors' access to this fiscal facility is poor structuring of potential guarantee 59 applications for projects. Wynne (2015) argued that many project sponsors seeking government 60 guarantee often fail to prove commercial viability of their business cases. According to HM 61 Treasury (2014), extensive due diligence appraisals are conducted on guarantee applications, 62 in a similar way to that carried out by project finance banks. As a result, project sponsors are 63 expected to present guarantee applications with strong potentials that can withstand 64 government set criteria and a test of viability (Wynne, 2015). However, while the existence of 65 government guarantee would understandably encourage project lenders towards financing PFI 66 projects, the unstable PFI market makes raising senior debt a challenge for sponsors (Connolly 67 and Wall, 2011; Johal et al., 2012). As such, many project lenders (banks) have avoided long68 term lending (Crotty, 2009; Johal et al., 2012; Demirag et al., 2015), while the available loan 69 deals are concentrated in few large projects (refer to Fig.1 below). Based on the foregoing facts, 70 the UK government still foresees shortage in market efficiency, coupled with sustained high 71 procurement costs (NAO, 2015; Demirag et al., 2015). 
fbn.

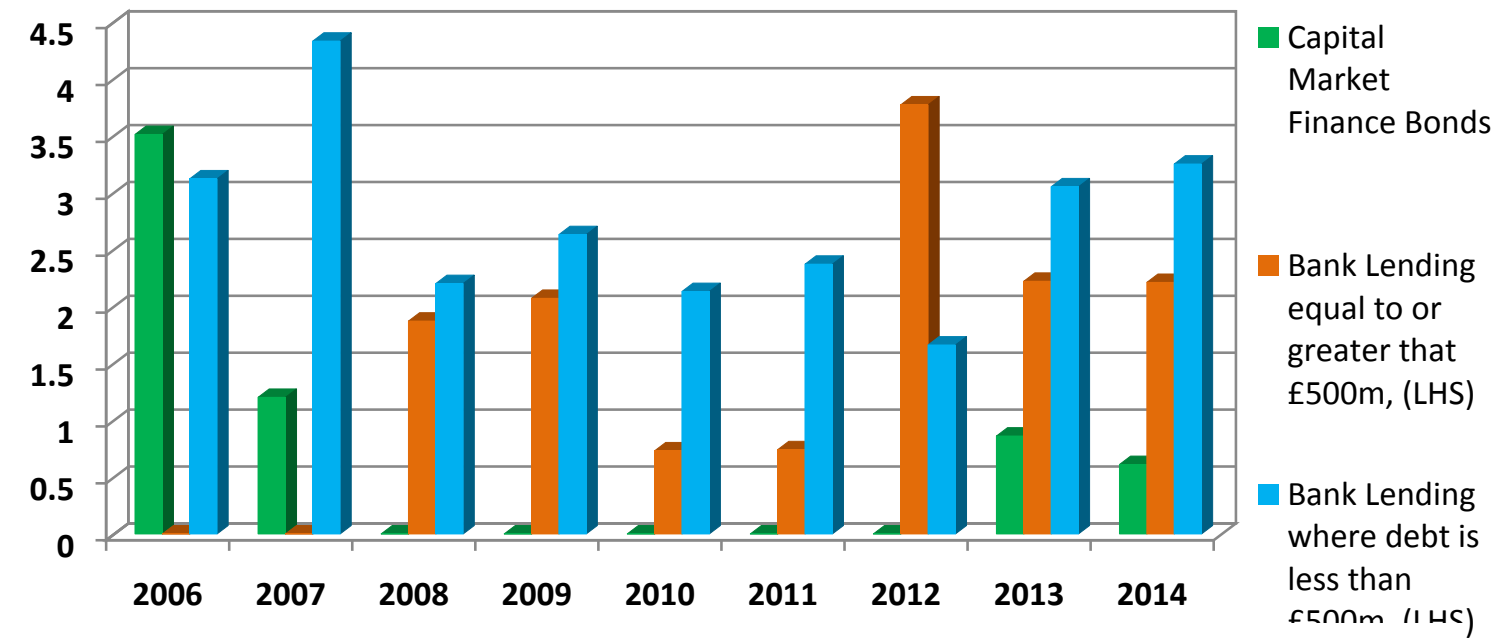

The graph reveals that banks lend to fewer PFI projects with value above $f 500 \mathrm{~m}$, compared to PFI projects of value below $1500 \mathrm{~m}$ over the 9-year period

72

73

74

75

76

77

Fig. 1. Volume of bank lending and bonds to UK PFI projects (£bn.) between $2006-2014$

\section{Adapted From National Audit Office (2015)}

Currently, the newly revised National Infrastructure Plan (NIP, 2014) has revalued UK's infrastructure needs as £466billion (HM Treasury, 2014). Two-thirds of these infrastructures are proposed to be funded via Private sector routes such as the PFI/PPP (NAO, 2015). Therefore, the big question that PPP stakeholders have continued to ask is what reliable strategies can be use by project sponsors in order to ensure successful government guarantee approval. The focus of this paper is to investigate PFI/PPP stakeholders' perspectives towards identifying the critical factors influencing successful government guarantee applications under the UKGSI.

In other to achieve the above aim, this study identified the following objectives:

1. To identify a robust and reliable set of criteria relevant for evaluating UK government guarantee for PFI/PPP infrastructure project during guarantee appraisal.

2. To explore the underlying critical factors necessary for PFI/PPP project sponsors to win guarantee scheme approval for infrastructure projects under the UKGSI. 
89 This study contributes to existing body of literatures on PFI/PPP procurement, by focusing on

90

91

92

\subsection{Post-Global Financial Crisis (GFC) in UK PFI/PPP Market and Emergence of} UK Guarantee Scheme for Infrastructures

In spite of the importance of PFI/PPP for financing public-oriented projects such as roads, rail network, hospitals etc. (Yang et al., 2013), the last global financial crisis created drastic reduction in loan available for numerous project finance contracts (Meng and McKevitt, 2011; Hampl et al; 2011; Demirag et al; 2011; Farrell, 2003). The world project finance market which attained a record high $\$ 68.6$ billion in 2008 suddenly plummeted by the end of 2009 to about $\$ 55.5$ billion due to the effect of the economic meltdown (Demirag et al, 2011). By the beginning of 2010, the value of bank lending to UK infrastructural projects had fallen from $£ 6$ billion pre-crisis level to $£ 3$ billion (NAO, 2015). A big gap between customer deposits and bank loans resulted (Thorhallsson and Kirby, 2012), as government's access to risk free borrowing drastically reduced (Toms et al., 2011). In addition, the new wave of financial 
regulations and structural revisions that followed, as an aftermath of the credit crunch, led to massive exodus of lenders from the PFI market (Demirag et al., 2015).

117 Amidst rising pressures on current infrastructures and budgetary constraints ((Hodge and 118 Greve, 2007; Demirag et al., 2015), the reality on ground presented governments with 119 enormous challenges in mobilising long-term finance for new infrastructures (HM Treasury, 2014). Due to this negative impact, reversing the dangerous trend and ensuring access to finance for critical infrastructures became a global agenda. This saw a number of developed economies such as the UK, US, Japan, Australia, China etc. massively roll out various economic and fiscal stimulus packages (Drew, 2010). The Obama administration rolled out the most massive bailout, injecting about \$US800 billion in fiscal stimulus package, into the US financial system (Garrett, 2010).

Following this trend, the UK Government in 2012, passed into law the Financial Assistance

Act. This act empowered the Treasury Department to provide financial guarantees for critical infrastructure in the UK $(\mathrm{NAO}, 2015)$ and resulted in the introduction of a 4year UK Guarantee

Scheme for Infrastructures (UKGSI). The UKGSI was conceived to provide an unconditional government cover for risks as well as other liabilities associated with financing large-scale infrastructures in UK. This HM Treasury’s policy was backed by a £40billion cover, which was made accessible to potential investors (project sponsors) in UK infrastructures. The scheme was to facilitate successful implementation of the 2011 National Infrastructure Plan (NIP). The NIP, which is a 5-year infrastructure master plan, is coordinated by Infrastructure UK (IUK), a department in the HM Treasury. The NIP highlighted priority sectors for new infrastructural investments within the UK economy. Additionally, the policy had earlier documented about 500 new infrastructure projects within the UK, requiring investments to the 
139 tune of $£ 250$ billion, with two-thirds of such investments to be privately financed using schemes 140 such as the PFI/PPP. See Fig.2 below for conceptual framework of the scheme and the focus 141 of the study:

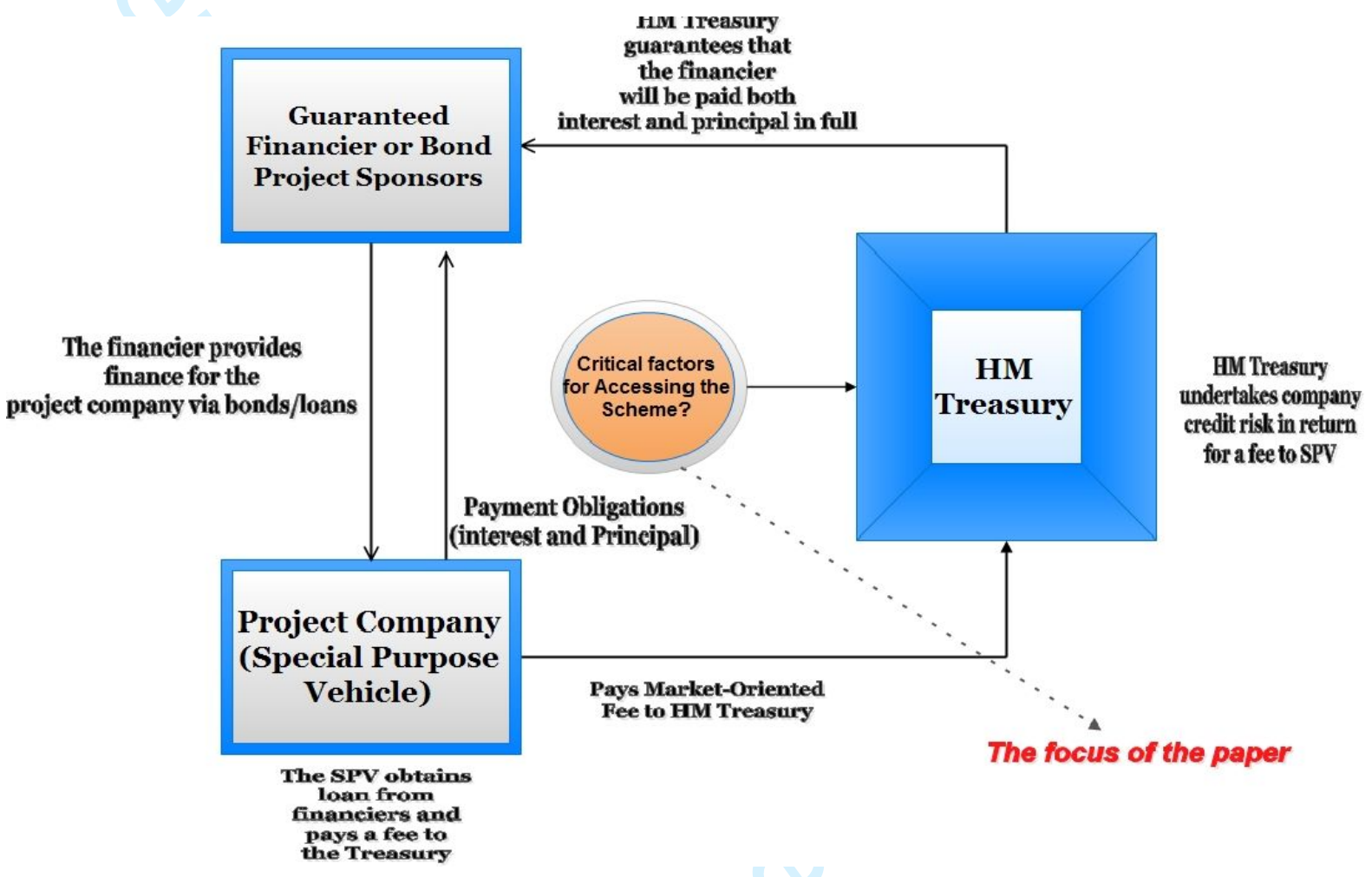

144 Fig.2. Conceptual Framework for UK Guarantee Scheme for Infrastructures

\section{Adapted from NAO, (2015).}

147 However, since the scheme's emergence, many project sponsors in UK infrastructures have 148 had difficulty accessing the guarantee (Wynne, 2015). While the NAO (2015) highlighted poor 149 structuring of projects' business case as the major barrier preventing sponsors' access to the 150 scheme, some sections among industry stakeholders highlighted poor understanding of the 151 guarantee scheme (Atmo and Duffield, 2014). This perspective confirms reports from HM 152 Treasury (2014) which stated that, apart from poor structuring of guarantee applications, many 153 project sponsors were unable to demonstrate how their proposed PFI projects met set criteria. Wynne (2015) had also challenged the absence of transparency and competitive bidding 
155 process in the guarantee scheme. Nevertheless, Treasury Department have maintained it 156 conducts its assessment of guarantee applications using best practices (HM Treasury, 2013).

158 According to HM Treasury (2014), as part of procedures for accessing the guarantee facility, 159 the treasury department conducts due diligence appraisals for project proposals similar to 160 commercial practice by project finance banks. Such appraisal involves risk assessments, 161 economic and technical feasibility of PFI projects. The treasury also ensures that, each 162 infrastructure project company is charged a non-refundable fee that is calculated based on 163 market-oriented benchmark on current prices of risk margins. This fee, it considers as value for 164 money to tax payers for accepting project risks. However, a number of criticisms have trailed the overall handling of the scheme and its impact on the entire UK PFI/PPP market (Carbonara et al., 2014; NAO, 2015; Wynne, 2015). Although the Treasury recorded her first guarantee in April 2013, by December 2014, only $£ 1.7$ billion of the $£ 40$ billion guarantee facility had been such public sector guarantees justifies its primary objectives (Carbonara et al., 2014; NAO, 2015; Gropp et al., 2014; Wynne, 2015). Therefore, in-depth understanding of critical factors needed by project sponsors to access the facility has been clamoured (Johal et al., 2012; Carbonara et al., 2014; Gropp et al., 2014; NAO, 2015).

\subsection{Research Methodology}

In order to deepen current understanding of critical factors for accessing the UK Guarantee

Scheme for Infrastructures (UKGSI), the need to explore the perspectives of PFI/PPP stakeholders and confirm wider applicability of such views necessitated the adoption of a twoway (explorative cum exploitative) methodological approach for the study. Described as 
181 "multiple operationism" by Webb et al. (1966), mixed methodology allows the combination of 182 methodologies in a single study. According to Denzin and Lincoln (2008), integrating 183 quantitative and qualitative data in a study is considered essential to increasing richness and 184 rigor in social inquiry. This buttressed Downward and Mearman (2007), who argued that, 185 through triangulation, qualitative findings can be validated using quantitative analysis and vice 186 versa. As such, by augmenting the non-overlapping weaknesses of either methods (qualitative 187 and quantitative), with strengths of the other (Johnson and Onwuegbuzie, 2004; Creswell, 2013); mixed methodology allowed research into the UKGSI to be robust. their daily experiences (Alversson and Deetz, 2000). This is in contradiction to the imposition of a priori theory, where the researcher simply tests a set of pre-defined factors identified from literature using a deductive methodology (Johnson and Duberley, 2000). As such, the focus group discussions helped to bring together stakeholders in UK's PFI industry to share their common understanding regarding the UK guarantee scheme; based on their previous involvement in PFI projects backed by government guarantee scheme. The focus groups comprised representatives of equity firms, senior lenders (banks), PFI/PPP contractors and public sector employees who have been involved in the UK guarantee scheme. By building on the views of one another through intersubjective interactions, participants were able to explore various perspectives on the scheme (Creswell, 2013). This provides deeper understanding into shared thinking on the topic of discussion (Chioncel et al., 2003). Thus, the major benefit here is that participants were able to remind one another of perceptions they may not have recalled, an approach which is unlikely in the case of one-on-one interviews (Oyedele, 2013). 
207 Considering the specialised nature of the UK guarantee scheme, identifying information-rich

208 participants with experience of the scheme required the adoption of purposive sampling 209 technique for the study. According to Blaikie (2000) and Neuman and Neuman (2006), 210 purposive sampling is best fitted for cases where the researcher intends to conduct in-depth 211 investigation about a unique type of study. This is more essential where the research 212 participants may not be easily reached (Marshall, 1996; Cooper et al., 2006). This sampling 213 approach therefore allowed the researcher to use wide network of contacts in the UK PFI 214 industry, to access suitable stakeholders for the study. Examples of previous studies in project 215 finance that had adopted this sampling approach are Bing et al. (2005), Li et al. (2005), Meng 216 and McKevitt (2011) and Oyedele (2013).

217

218 In order to explore participants' common understanding of the phenomenon, four (4) focus 219 group discussions were conducted in all. Eighteen participants were involved in the focus group 220 discussions comprising, four (4) public sector employees, four (4) senior lenders (banks staffs), 221 six (6) staff of equity investment firms and four (4) PFI/PPP contractors. In total, all the 222 discussants have been involved in an average of 36 PFI/PPP project finance deals in their 223 career. Additionally, the total numbers of UKGSI applications personally involved in by all 224 participants were 16. The entire focus group discussions lasted 467mins. Table 1 shows further 225 description of participants in the group:

226 Table 1: Overview of Participants involved in the Focus Group Discussions

\begin{tabular}{|c|c|c|c|c|c|c|}
\hline FG & Categories of Focus Group Participants & $\begin{array}{l}\text { Public } \\
\text { Sector } \\
\text { employees }\end{array}$ & $\begin{array}{l}\text { Senior } \\
\text { Lenders }\end{array}$ & $\begin{array}{l}\text { Equity } \\
\text { Investors }\end{array}$ & $\begin{array}{l}\text { PFI/PPP } \\
\text { Contractors }\end{array}$ & Total \\
\hline 1. & No. of Interview Participants & 4 & 4 & 6 & 4 & 18 \\
\hline 2. & $\begin{array}{l}\text { Average experience of participants in PFI/PPP } \\
\text { Project financing }\end{array}$ & 7years & 9 years & 8years & 10years & $34 y r s$ \\
\hline 3. & Duration of focus group discussions & $75 \mathrm{mins}$ & $112 \mathrm{mins}$ & 160mins & $120 \mathrm{mins}$ & $467 \mathrm{mins}$ \\
\hline \multirow[t]{2}{*}{4.} & $\begin{array}{l}\text { Job Title of interview participants: } \\
\text { - Mid-level Staffs }\end{array}$ & 0 & 0 & 2 & 0 & \\
\hline & - Senior Staff & 3 & 0 & 0 & 2 & 5 \\
\hline
\end{tabular}


6. No. of UKGSI applications involved

228 Discussions in each focus group explored experiences of various participants regarding

229 PFI/PPP projects with emphasis on their involvement in UKGSI applications for projects.

230 Issues such as how to ensure project bankability and criteria for ensuring successful guarantee

231 applications were examined. Data collected from the focus group interviews were later

232 transcribed and analysed using Nvivo10 software. From the qualitative data transcript, the

233 author identified a comprehensive list of 26 important factors influencing the success of

234 UKGSI guarantee applications for potential PFI/PPP infrastructure projects.

236 The second phase of the study involved postal questionnaire survey developed using the criteria identified through focus group discussions. The adoption of questionnaire survey for this study centred on the need for wider applicability and reliability of findings generated from the qualitative study (Oyedele, 2013). Questionnaire respondents were identified via the UK PFI projects' database provided by Partnership UK. From this database, a list of three hundred and 241 five (305) financial and contracting firms, comprising senior lenders (banks), equity firms,

242 financial consultants, hedge funds, pension fund managers, PFI/PPP contractors etc. were collated. The survey was piloted using three academics (in project management field), four lenders (staff) and two financial consultants, all of whom possess an average of 15.3 years' experience in PFI/PPP deals in various capacities. Their feedback, which included rephrasing, and shortening of few questions were carried out, to develop the final questionnaire. In the final questionnaire, respondents were individually required to indicate the importance of criteria determining approval for PFI projects under the UK guarantee scheme for infrastructures. This 
252 Distribution of the survey to various respondents was done via postal mail and accompanied 253 by a letter of introduction to the study, as well as a return envelope each. Out of the two hundred 254 and seventy one (271) questionnaires distributed, 195 questionnaires were returned amounting 255 to a response rate $71.95 \%$. Thirty-eight (38) of the questionnaires were incomplete and 256 therefore rejected. This left us with a total of one hundred and fifty seven (157) usable 257 responses from senior lenders (banks), equity firms, financial consultants and PFI/PPP 258 contractors, representing $57.93 \%$ of distributed questionnaires. Data collected from the 259 questionnaire survey was later analysed using Statistical Package for Social Sciences (SPSS) 260 Software. Factor Analysis, which allowed the exploration and identification of the principal 261 underlying dimensions behind the phenomenon, was conducted. This is in addition to 262 identifying the importance of each criterion from the questionnaire using a Significant Index Rating. Table 2 shows the summary of sample response from the survey respondents. From 264 Table 2, the response rate were, $86.5,80,86.4$, and $57.3 \%$ comprising senior managers of 265 banks, financial consultants, directors of equity firms, construction site managers respectively.

266 This was considered suitable for analysis based on the claim by Oyedele (2013) that a survey 267 result could be considered to be of little significance and biased if the rate of return was lower 268 than 30 to $40 \%$. All the respondents have been involved in an average of 21 UK Guarantee 269 Applications for PFI/PPP projects.

270

Table 2. Sample Responses from Questionnaire Survey

\begin{tabular}{|l|c|c|c|c|c|}
\hline Professionals & $\begin{array}{l}\text { Number } \\
\text { Distributed }\end{array}$ & $\begin{array}{l}\text { Number of } \\
\text { Responses }\end{array}$ & $\begin{array}{l}\text { Percentage } \\
\text { (\%)Return }\end{array}$ & $\begin{array}{l}\text { Av. years of } \\
\text { Experience }\end{array}$ & $\begin{array}{l}\text { Av. No. of PFI } \\
\text { Projects } \\
\text { Involved with }\end{array}$ \\
\hline Senior Managers (Banks) & 67 & 58 & 86.5 & 21.5 & $20-25$ \\
Hedge Funds Managers & 25 & 11 & 44 & 12.0 & $20+$ \\
Financial Consultants & 40 & 32 & 80 & 15.5 & $25+$ \\
Equity Investments Directors & 59 & 51 & 86.4 & 17.0 & $25-30$ \\
PFI/PPP Contractors & 61 & 35 & 57.3 & 15.0 & $20-25$ \\
\hline
\end{tabular}




8

195

42.1

71.95

13.0

15.6

5+

$25+$

\subsection{Analyses of Data}

273 This section discusses the qualitative and quantitative analyses of findings from focus group 274 discussions with UK PFI industry stakeholders and responses from questionnaire survey as 275 regards the UK guarantee scheme.

276

277

278

According to Creswell (2013), qualitative data analysis involves identifying significant statements, meaning units, structural and textual themes that highlight the essence of a phenomenon. This approach allows the researcher to transit from narrow units to broader units of analysis (Alversson and Deetz, 2000). After extensive discussions that spanned a total of 467mins where participants explored various perspectives on the UKGSI, transcripts of the discussions were produced using Nvivo10 software. The author carefully read the data transcripts on several occasion, while identifying various themes from experiences of industry experts. After thorough analysis of the qualitative data, 26 important criteria that can influence chances of winning UKGSI approval for potential infrastructure projects.

291

292 293

Table 3: Important Criteria Influencing Approval for UK Guarantee Scheme

\begin{tabular}{|c|c|c|c|c|c|}
\hline No & \multirow[t]{2}{*}{ Criteria for Accessing the UK Guarantee Scheme for Infrastructures } & \multicolumn{4}{|c|}{ Focus Groups } \\
\hline & & 1 & 2 & 3 & 4 \\
\hline 1 & - Project is infrastructure in NIP-defined priority sectors. & $\checkmark$ & $\checkmark$ & $\checkmark$ & $\checkmark$ \\
\hline 2 & - Compliance of project with European Commission guidance on state guarantees & $\checkmark$ & $\checkmark$ & $\checkmark$ & $\checkmark$ \\
\hline
\end{tabular}


- Project must be nationally or economically significant in nature (Large scale).

4 - Project must be non-investment grade due to high construction risk

5 - Strong financial credibility of project.

6 - Project must be technically feasible.

7 - Existence of front-ended equity commitment from sponsors.

8 - Project must have robust risk structuring and management framework

9 - Competence of project consortium members

10 - Project must have obtained approval and permit from authorities

11 - Project's readiness to start construction within 52weeks of guarantee.

12 - Existence of delay in start-Up insurance by project consortium.

13 - Project's compliance with other legal and regulatory laws.

14 - Project demonstrates how inadequate finance will hinder project.

15 - Project demonstrates the viability.

16 - Consortium proves lenders' risk aversion and desire for more financial cover.

17 - Consortium proves how absence of guarantee will damage project time scales

18 - Clear identification of level of risk exposure in the project

19 - Projects must have acceptable credit quality.

20 - Compliance with social, legal and environmental laws and standards.

21 - Efficient risk transfer away from tax payers.

22 - Project's affordability

23 - Project offers least Cost of procurement.

24 - Project offers opportunity for technological transfer

25 - Project offers innovative designs and strategies.

26 - Market-oriented fee commensurate to risk borne by the tax payers.

295 The focus group discussions were also used to identify participants' perspectives on issues such 296 as:

- Divergent stakeholders' opinions regarding various guarantee criteria.

\subsection{Quantitative Analysis and Findings}


301 Since one of the objectives of this study is to identify a reliable set of criteria used in evaluating

302 UK government guarantee applications, reliability analysis was conducted. With the aid of

303 Statistical Package for Social Sciences (SPSS), the Cronbach's Alpha reliability coefficient for 304 the 26 criteria was produced as 0.904 . According to Field (2005), a high reliability coefficient 305 usually above 0.7 confirms the greater internal consistency of the entire data to measure the 306 construct it was aimed to measure statistically. Oyedele (2013) indicate that any factor not 307 contributing to the internal consistency of the data will have a higher reliability score than the 308 overall Cronbach's alpha reliability coefficient (i.e. in this study, it is 0.904). Based on the 309 results shown in the third column of Table 4, the 26 set of criteria show strong reliability in 310 evaluating UK government guarantee applications for PFI/PPP infrastructure projects.

312 After the reliability analysis, this study was interested to know the significance ranking of each criterion. A significance index used by similar studies Tam et al. (2000) and Spillane et al.

314 (2012) was used. This is mathematically expressed as:

316 Where $s$ represents the significance rating on a Likert scale of 1 to $5, \mathrm{~S}$ is the highest

317 significance rating (that is 5) and $\mathrm{N}$ is the total number of responses for that particular factor.

318 The significance index and ranking are shown in column four and five of Table 4 respectively.

319 The top five most significant criteria for evaluating UK government guarantee scheme are (i) 320 project must be nationally or economically significant in nature (ii) project must be 321 infrastructure in NIP-defined priority sectors (iii) compliance of project with European 322 Commission's guidance on state guarantees (iv) strong financial credibility of project (v) 323 project must be non-investment grade due to high construction risk. Likewise, the least five 324 criteria for evaluating UK government guarantee scheme for infrastructures, as confirmed by 
the respondents are: (i) project offers innovative design and strategies (ii) project offers

326

327

328

330

331

332

333

334

335

336

337

338

339

340

341

342

343

344

opportunity for technological transfer (iii) existence of delay in start-up insurance by project consortium (iv) consortium proves lender's risk aversion and desire for more financial cover (existence of front-ended equity commitment from sponsors.

\section{Factor Analysis}

After ascertaining the significance of each criterion, in line with the main objective of the study, which is to unravel the dominant structures underlying the various criteria, exploratory factor analysis was conducted. Factor analysis is a statistical technique used for data reduction or structure detection in which variability in observed or correlated items are identified from other smaller variables (Meredith, 1993). With factor analysis, a set of key uncorrelated factors are unravelled from the reduced data. The Kaiser-Meyer-Olkin (KMO) measure of sampling adequacy value and Bartlett test of sphericity were 0.63 (higher than 0.5) and 8.1018e-34, less than 0.05 respectively. These two tests confirm that the data is appropriate for factor analysis. Principal Axis Factor and Varimax rotation were used for criteria extraction and rotation respectively. In order to assist in the interpretation of findings, all criteria with Eigen value of 1 and above were extracted. In addition, all criteria with factor loading of 0.50 and above were picked for grouping the criteria (Tucker and Lewis, 1973). The analysis shows five factorsolution with Eigen values greater than one (1) as shown in column three and five of Table 5. See also Fig. 3 for the associated Scree Plot revealing the graphical representation of the five critical factors. The five factor-solution account for $77.22 \%$ of total variance and were considered the critical factors influencing PFI project's approval under the UK guarantee Scheme for Infrastructures. All the critical factors are labelled with due cognizance to the criteria that made them up. These are listed below

\section{Critical Factor 1 : Project Compliance with UK National Infrastructure Plan}


350 -

351- Critical Factor 3: Projects' Demonstration of Value for Money to Tax Payers.

352 - Critical Factor 4: Demonstrate Project's Dependence on the UK Guarantee Scheme.

353- Critical Factor 5: Certainty of Planning Commission's Approval.
355

356

357

358

359

360

361

362

363

364

365

366
Scree Plot

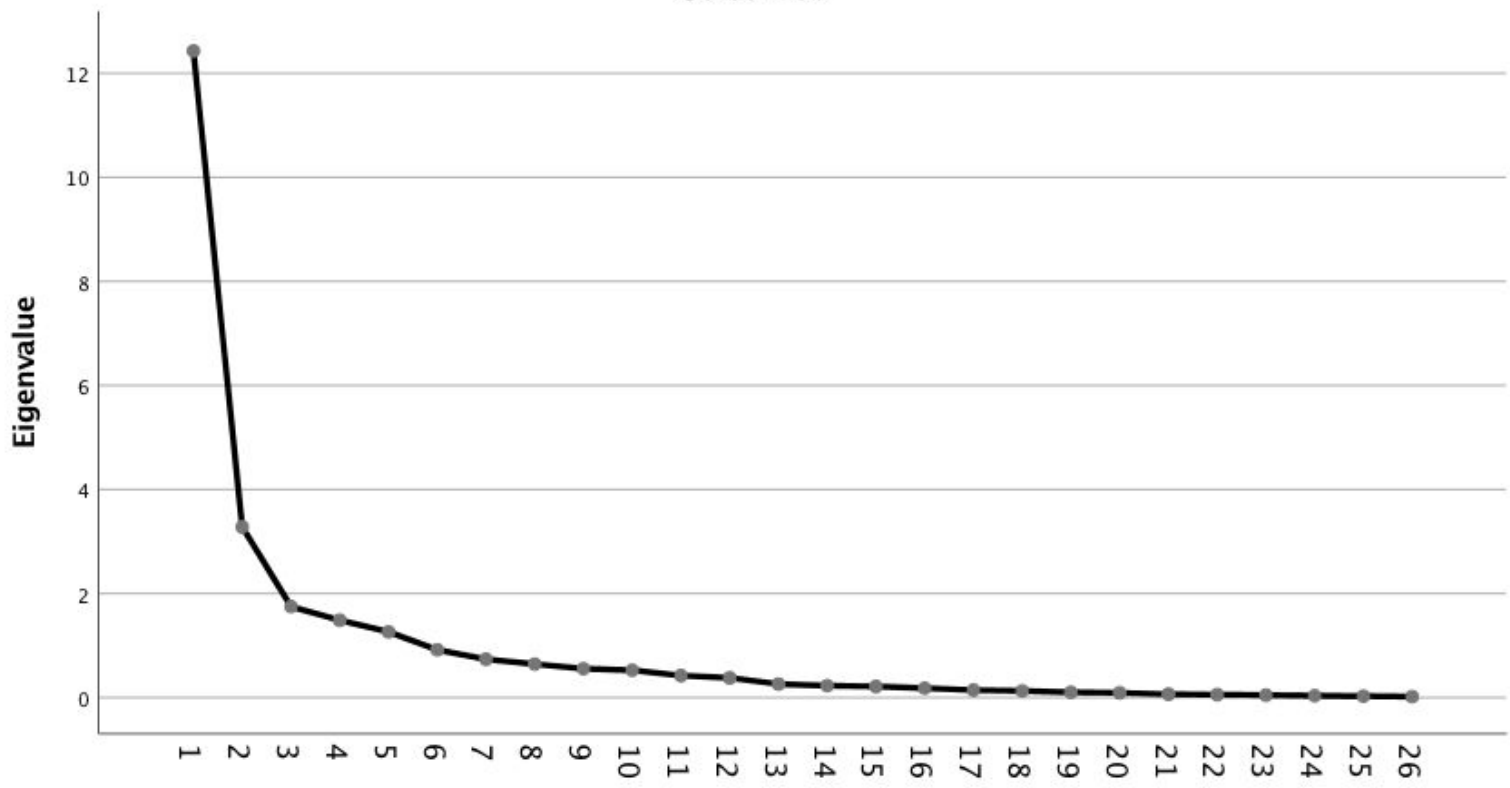

Component Number

\subsection{Discussion of Findings}

This section discusses findings from the study by buttressing results from questionnaire survey with expert opinions from focus group discussions. The discussions are based on the five critical factors below:

\section{Critical Factors for Winning the UKGSI Guarantee Approval}

Using the Eigen value as a measure of criteria grouping's significance; evidences from survey responses produced five (5) critical factors for winning guarantee approval. Table 5 below 
367 showed that three of the critical factors displayed higher Eigen value of 4.73, 3.95 and 2.67.

368 This suggests higher importance rating of the critical factors from respondents; with respect to

369 influencing UK guarantee scheme's approval for projects. While the remaining two factors'

370 Eigen values are 2.57 and 1.22 respectively. Studies on PFI/PPP project financing such as Li

371 et al. (2005); Zhang (2005); Ahadzi and Bowles (2004) have adopted similar statistical method.

372 CF1. Project's Compliance with National Infrastructure Plan (NIP)

373 As shown in Table 5 below, project's compliance with the NIP ranked highest in the survey 374 analysis (see Table five: Eigen value of 4.73) and is identified as the most important parameter 375 for winning guarantee approval under the UK Guarantee Scheme for Infrastructure (UKGSI).

376 These perspectives confirm the views from focus group discussions as reflected by one of the 377 participants who argued that: 
Table 4: Reliability Analysis \& Significance Ranking of Factors Influencing Approval for UK Guarantee for PFI Infrastructures

\begin{tabular}{|c|c|c|c|c|}
\hline No & Factors Determining PFI project's Approval for UK Guarantee Scheme for Infrastructures & $\begin{array}{l}\text { Cronbach's } \alpha \\
\text { if items } \\
\text { deleted }\end{array}$ & $\begin{array}{l}\text { Significance } \\
\text { Index (\%) }\end{array}$ & $\begin{array}{l}\text { Criteria } \\
\text { Ranking }\end{array}$ \\
\hline F.1 & Project compliance with UK National Infrastructure Plan & & & \\
\hline F1a & $\begin{array}{l}\text { Criteria: } \\
\text { - Project is infrastructure in NIP-defined priority sectors. }\end{array}$ & 0.900 & 95.20 & 2 \\
\hline F1b & - Compliance of project with European Commission's guidance on state guarantees & 0.902 & 94.20 & 3 \\
\hline F1c & - Project must be nationally or economically significant in nature (Large scale). & 0.899 & 98.50 & 1 \\
\hline \multirow[t]{2}{*}{ F1b } & - Project must be non-investment grade due to high construction risk. & 0.897 & 87.40 & 6 \\
\hline & $\sqrt{2}$ & & & \\
\hline F.2 & Demonstration of project bankability and risk management & & & \\
\hline $\mathrm{F} 2 \mathrm{a}$ & $\begin{array}{l}\text { Criteria: } \\
\text { - Strong financial credibility of project. }\end{array}$ & 0.901 & 93.10 & 4 \\
\hline $\mathrm{F} 2 \mathrm{~b}$ & - $\quad$ Project must be technically feasible. & 0.900 & 85.10 & 7 \\
\hline $\mathrm{F} 2 \mathrm{c}$ & - Existence of front-ended equity commitment from sponsors. & 0.879 & 41.10 & 26 \\
\hline F2d & - Project must have robust risk structuring and management framework & 0.902 & 81.80 & 9 \\
\hline \multirow[t]{2}{*}{$\mathrm{F} 2 \mathrm{e}$} & - Competence of project consortium members & 0.893 & 55.90 & 21 \\
\hline & \\
\hline F.3 & \multicolumn{4}{|l|}{ Projects' Demonstration of Value for Money to tax payers. } \\
\hline F3a & $\begin{array}{l}\text { Criteria: } \\
\text { - Projects must have acceptable credit quality }\end{array}$ & 0.847 & 91.50 & 5 \\
\hline F3b & - Compliance with social, legal and environmental laws and standards & 0.890 & 69.90 & 16 \\
\hline F3c & - Efficient risk transfer away from tax payers & 0.904 & 79.80 & 11 \\
\hline F3d & - $\quad$ Project's affordability & 0.902 & 83.70 & 8 \\
\hline F3e & - $\quad$ Project offers least Cost of procurement & 0.902 & 81.30 & 10 \\
\hline F3f & - $\quad$ Project offers opportunity for technological transfer & 0.878 & 49.50 & 23 \\
\hline F3g & - $\quad$ Project offers innovative designs and strategies & 0.898 & 51.70 & 22 \\
\hline F3h & - Market-oriented fee commensurate to risk borne by the tax payers & 0.895 & 74.70 & 12 \\
\hline F.4 & \multicolumn{4}{|l|}{ Demonstrate project's dependence on the UK Guarantee Scheme } \\
\hline F4a & $\begin{array}{l}\text { Criteria: } \\
\text { - Project demonstrates how inadequate finance will hinder project }\end{array}$ & 0.903 & 61.50 & 19 \\
\hline $\mathrm{F} 4 \mathrm{~b}$ & - $\quad$ Project demonstrates the viability & 0.901 & 71.40 & 15 \\
\hline $\mathrm{F} 4 \mathrm{c}$ & - Consortium proves lenders' risk aversion and desire for more financial cover & 0.899 & 42.90 & 25 \\
\hline F4d & - Consortium proves how absence of guarantee will damage project time scales & 0.902 & 58.30 & 20 \\
\hline \multirow[t]{2}{*}{$\mathrm{F} 4 \mathrm{e}$} & - Clear identification of level of risk exposure in the project & 0.896 & \multirow{2}{*}{\multicolumn{2}{|c|}{$0 / .10$}} \\
\hline & & & & \\
\hline F.5 & Certainty of Planning Commission's Approval & 0.904 & & \\
\hline F5a & $\begin{array}{l}\text { Criteria: } \\
\text { - Project must have obtained approval and permit from authorities }\end{array}$ & 0.903 & 73.90 & 13 \\
\hline $\mathrm{F} 5 \mathrm{~b}$ & - Project's readiness to start construction within 52 weeks of guarantee. & 0.901 & 72.80 & 14 \\
\hline F5c & - $\quad$ Existence of delay in start-Up insurance by project consortium. & 0.898 & 44.30 & 24 \\
\hline F5d & - $\quad$ Project's compliance with other legal and regulatory laws. & 0.901 & 63.20 & 18 \\
\hline
\end{tabular}

Overall Cronbach' Alpha $=0.904$, Significant at 95\% Confidence interval $=0.05$ 


\section{Table 5: Factor Analysis for the Criteria Influencing Approval for UK Guarantee for PFI Infrastructures}

\begin{tabular}{|c|c|c|c|c|}
\hline No & & $\begin{array}{l}\text { Eigen } \\
\text { Value }\end{array}$ & $\begin{array}{c}\% \\
\text { Variance } \\
\end{array}$ & $\begin{array}{l}\text { Factor } \\
\text { Loading }\end{array}$ \\
\hline F.1 & Project compliance with UK National Infrastructure Plan & 4.737 & 35.67 & \\
\hline F1a & $\begin{array}{l}\text { Criteria: } \\
\text { - Project is infrastructure in NIP-defined priority sectors. }\end{array}$ & & & 0.843 \\
\hline F1b & $\begin{array}{l}\text { - Compliance of project with European Commission's guidance on state } \\
\text { guarantees }\end{array}$ & & & 0.801 \\
\hline F1c & - Project must be nationally or economically significant in nature (Large scale). & & & 0.687 \\
\hline F1b & - Project must be non-investment grade due to high construction risk. & & & 0.585 \\
\hline F.2 & Demonstration of project bankability and risk management & 3.952 & 19.22 & \\
\hline F2a & $\begin{array}{l}\text { Criteria: } \\
\text { - Strong financial credibility of project. }\end{array}$ & & & 0.739 \\
\hline F2b & - $\quad$ Project must be technically feasible. & & & 0.657 \\
\hline F2c & - $\quad$ Existence of front-ended equity commitment from sponsors. & & & 0.623 \\
\hline F2d & - $\quad$ Project must have robust risk structuring and management framework & & & 0.575 \\
\hline F2e & - $\quad$ Competence of project consortium members & & & 0.804 \\
\hline F.3 & Projects' Demonstration of Value for Money to tax payers. & 2.674 & 11.14 & \\
\hline F3a & $\begin{array}{l}\text { Criteria: } \\
\text { - Projects must have acceptable credit quality }\end{array}$ & & & 0.622 \\
\hline F3b & - Compliance with social, legal and environmental laws and standards & & & 0.540 \\
\hline F3c & - $\quad$ Efficient risk transfer away from tax payers & & & 0.773 \\
\hline F3d & - $\quad$ Project's affordability & & & 0.638 \\
\hline F3e & - $\quad$ Project offers least Cost of procurement & & & 0.586 \\
\hline F3f & - $\quad$ Project offers opportunity for technological transfer & & & 0.517 \\
\hline F3g & - $\quad$ Project offers innovative designs and strategies & & & 0.864 \\
\hline F3h & - $\quad$ Market-oriented fee commensurate to risk borne by the tax payers & & & 0.858 \\
\hline F.4 & Demonstrate project's dependence on the UK Guarantee Scheme & 2.578 & 7.05 & \\
\hline F4a & $\begin{array}{l}\text { Criteria: } \\
\text { - } \quad \text { Project demonstrates how inadequate finance will hinder project }\end{array}$ & & & 0.718 \\
\hline F4b & - $\quad$ Project demonstrates the viability & & & 0.621 \\
\hline F4c & - Consortium proves lenders' risk aversion and desire for more financial cover & & & 0.583 \\
\hline F4d & - Consortium proves how absence of guarantee will damage project time scales & & & 0.869 \\
\hline F4e & - $\quad$ Clear identification of level of risk exposure in the project & & & 0.692 \\
\hline F.5 & Certainty of Planning Commission's Approval & 1.229 & 4.14 & \\
\hline F5a & $\begin{array}{l}\text { Criteria: } \\
\text { - Project must have obtained approval and permit from authorities }\end{array}$ & & & 0.661 \\
\hline $\mathbf{F 5 b}$ & - $\quad$ Project's readiness to start construction within 52weeks of guarantee. & & & 0.549 \\
\hline F5c & - $\quad$ Existence of delay in start-Up insurance by project consortium. & & & 0.611 \\
\hline F5d & - $\quad$ Project's compliance with other legal and regulatory laws. & & & 0.537 \\
\hline & Total & & 77.22 & \\
\hline
\end{tabular}




\section{"Projects of national significance with full compliance to the NIP and European commission's guarantee guidance are majorly targeted under the guarantee scheme.” (Focus Group 3)}

In line with the above assertion, the National Planning Commission described nationally significant projects as projects classified as large-scale developmental projects that meet a broad classification of infrastructure, ranging from transport, health, waste, energy, education, courts, prisons etc. As discovered during the course of the study, infrastructures in these priority sectors, and especially in transport and energy sectors, have been considered to be of priority. This confirms the UK government's economic agenda to deliver sustainable and effective transport system for the UK in order to allow businesses and people to prosper, while reducing greenhouse gas emissions using more renewable/low carbon energy (Wynne, 2015). To this end, UKGSI allows the Treasury to guarantee large and innovative projects, which may be non-investment grade. Non-investment grade projects are high yield investment portfolio with relatively low credit quality and higher risk of default (Rigobon, 2002). Such projects are often rated below 'BBB' from Standard and Poor's rating agency and 'Baa' from Moody's (Hite and Warga, 1997). From the Treasury's perspectives, most large infrastructures are often non-investment grade (NAO, 2015), given their typically higher construction risks (Dailami and Klein, 1997). However, potential projects have to demonstrate potentials for improving credit quality over the course of time and a contribution to economic growth (Wynne, 2015). The criterion of project's contribution to economic growth has however generated divided opinions among focus group discussants, with most private sector participants (Equity investment firms, senior lenders, contractors), describing the criterion as very ambiguous. A typical quote suggests that:

"One of the major criterion that sponsors may find difficult to address is to prove a project's contribution to economic growth, considering the absence 
of any objective testing criteria for such from the government. There are certain aspects that seem rather subjective”. (Focus Group 4)

However, public sectors participants argue that, such criteria are left to the internal decisions of the Treasury but may be influenced by the novelty of such project and its wider impact on the UK as a whole. Additionally, findings also reveal that projects with higher than $5 \%$ default risk in any particular year stand little chance of being guaranteed, since that contravenes the European Commission's guideline on guarantee scheme. The availability of relevant price benchmarks for non-investment grade risks in the project will better project assessment.

\section{CF.2 Demonstration of Project Bankability and Risk Management}

Project bankability and risk management ranked next in importance based on evidence from survey responses as shown in Table 5 with an Eigen value of 3.95. This result suggests that, given the high-risk nature of PFI/PPP projects, bankability remains the next crucial factor to consider (Yescombe, 2013). As such, a project is not considered bankable where risks related to its' commercial viability have not been identified, allocated and mitigated within the project structure from a commercial perspective (Meng and McKevitt, 2011). These perspectives confirm opinions expressed by focus group discussants as summed-up by a senior lender who argued that:

\section{"The crucial thing here is that the project must demonstrate bankability. In reality bankability is actually the starting point for any project financing, and the guarantee scheme prioritises this as well...." (Focus Group 1)}

In line with the above assertion, HM Treasury (2013) highlighted that; projects must demonstrate bankability by satisfying minimum bankability requirements. Bankability in PFI/PPP projects requires that the commercial terms of a project be satisfactory to lenders. This emphasizes the 
project's ability to generate sufficient income that enables debt repayments to financiers and returns on investments to project sponsors (Meng and McKevitt, 2011). According to Delmon (2011), projects must show robustness in cash flow projections that is based on adequate Debt Service Cover Ratio (DSCR) over the project life cycle. Zhang (2005) argued that financial robustness in PFI projects is often hinged on successful project completion, which marks the end of construction stage. As such, assurances that such project will be successfully constructed within financial budget and stipulated time will require technical competence on the part of the project consortium (Akintoye et al., 1998). In that respect, competent construction contractor with wealth of experience in such projects, financial strength and tried-and-tested project technology will boast project bankability (Mills, 2010).

Results also show that, since most PFI/PPP projects are often front-loaded in terms of capital involvement at the construction stage, sponsors may enhance bankability chances by agreeing to a front-ended equity injection. Front-ended equity stake in PFI projects (sponsors put in all their capital from project commencement), is seen as a huge demonstration of commitment from project sponsors towards the success of the project (Hoffman, 2008). Evidence also show that, where a guarantee application demonstrates strong understanding of project risks and capability to efficiently allocate and manage such risks in manner that unburdens the public sector, more bankability is conferred on such project. This buttressed Gropp et al. (2014), who argue that, the public sector is not involved in speculative businesses, and as such, any risk transfer to public sector under any guise must not be at the expense of the taxpayers. Therefore, competence on the part of the project consortium will ultimately inform the series of financial, technical and managerial decision that will ensure the bankability of projects (Mills, 2010), and a successful guarantee bid. 


\section{CF3. Projects' Demonstration of Value for Money to Tax Payers}

Value for money ranked third as a parameter influencing approval for UKGSI. This is evidenced by survey results in Table 5, with an Eigen value of 2.67. Value for money (VFM) to tax payers is considered a critical parameter for winning the UKGSI guarantee. In November 1994, the UK government mandated all public sector procurements to pass through value for money test (Akintoye et al., 2003). Here, the HM Treasury puts all procurements, using private sector finances, under three cardinal criteria namely: cost savings in comparison to cost of direct traditional procurements (using public sector comparator), affordability and efficient risk transfer away from the public sector (Cheung et al., 2009). Finding show that, asides charging marketoriented fee to guaranteed project companies (which is considered the most important factor under the UKGSI VFM test, the value for money assessment also involves examining the viability of the project, social and environmental impact assessments, opportunities for innovative designs and strategies, etc.

However, the need for guarantee applications to fulfil value for money criteria generated various perspectives among focus group participants. While participants expressed collective views concerning the importance of VFM, they expressed different opinions on the number of VFM tests required for projects applicants under the scheme. Most private sector participants (senior lenders, equity investors and PFI/PPP contractors) in the focus group considered the scheme's VFM test as cumbersome. As one discussant argued:

"Let's not forget that in a PFI project, there is VFM test, during the bidding stage where the public sector clients expect a demonstration of VFM. Therefore having another VFM test at the guarantee stage simply is too much bureaucracy 
to the current system... and obviously something has to be done to our regulatory regimes.” (Focus Group 2)

From public sector participants' opinions, the current VFM test only examines whether the fee charged to project companies for obtaining government guarantee represents value to tax payers or not. This approach to VFM, according to many participants, is not holistic enough. As exemplified in the views of one participant:

"Value for money ensures the project does not present any fiscal or economic risk to the financial system. But quite frankly.... the challenge here is that we can't just simply look at the fees charged by the Treasury on guaranteed projects as representing VFM, while neglecting the aspect of whether the project itself represents VFM. So there is still need for bottom up approach on VFM in the scheme“. (Focus Group 3)

This perspective buttressed a recent study by Gropp et al. (2014) who argued that public sector guarantees have been argued to represent another on-balance sheet financing for governments, and as such, require proper management to the extent that it galvanises lending markets to their traditional roles.

\section{CF4. Demonstration of Project's Dependence on the UK Guarantee Scheme}

Dependence on UK Guarantee Scheme for Infrastructure is also another critical factor that influences guarantee approval under the UKGSI. Table 5 indicate an Eigen value of 2.57 from the survey results. As argued by NAO (2015), justifying the reliance of a proposed project on government guarantee is essential upon the objective that the UKGSI is not designed to grant direct infrastructure loans to project sponsors. As such, the facility must serve targeted audiences and prevent a situation where sponsors obtain guarantee for projects that could have been financed independently with no recourse to the scheme (HM Treasury, 2014). These arguments 
also reflect perspectives from focus group discussions as aptly captured by one of the participants who argue that:

"The scheme will only consider projects that prove how it cannot go ahead without the backing of UKGSI guarantee. There are several ways of proving that, but of course there is no point providing guarantee to projects who have no business been guaranteed" (Focus Group 1).

Wynne (2015) buttressed the above assertions by arguing that, it is essential to avoid investors' undue exploitation of the public sector guarantee. This is because when providing guarantees, the public sector may incur significant contingent liabilities, such that if called upon to be paid, can be an enormous financial obligation (Wibowo and Kochendoerfer, 2010). Tiong (1995) argued that it is not logical for the public sector to allow project sponsors to simply make money while the risks in a project are passed down to the tax payers. To this end, guarantee applications must demonstrate how such PFI projects are not financeable from a commercial point of view. Findings show that sponsors may need to clearly articulate a detailed framework of barriers to such project investments in terms of identifying high-risk profile of such projects, which therefore makes such a non-investment grade investment, and thus require government guarantee support. Other strategies may include a demonstration of the benefits and significance of such PFI project to the economy that makes it laudable (e.g. low carbon emission projects, reducing travel time on transport links etc.). Evidences of the prior financiers' verdicts on the projects weak prospects on a commercial level due to enormous technical and other risk risks may also confer some weight on the justification (Tiong, 1995; Kumaraswamy and Zhang, 2001). In addition, evidences of the credit quality rating of such project from credit rating agencies (e.g. Moody's, Standard \& Poor's, and Fitch) may give further impetus to the application concerning its weak credit rating (Wibowo and Kochendoerfer, 2010). 


\title{
CF5. Certainty of Planning Commission's Approval
}

Obtaining planning commission permit ranked least with respect to its' influence on winning UK guarantee approval for PFI projects, based on results from survey analysis with an Eigen value of 1.22 (see Table Five). The need for planning permit was highlighted during the focus group discussions as one discussant argues that:

\begin{abstract}
“The planning commission's permit has been part of the system for years with respect to any development project in the UK. But the challenge here for sponsors has always been delays to obtaining planning permits and this has stalled many guarantee applications for important infrastructures" (Focus Group 4).
\end{abstract}

The need to obtain planning permit was highlighted by Mills (2010) and Wibowo and Kochendoerfer (2010), who argued that obtaining planning permits and approval for construction and operations of PFI projects is crucial to public sector guarantee for BOT projects. According to Mills (2010), such permit represents a major confirmation that the project sponsors are hoping to commence serious construction and operations of projects in earnest. Further evidences show that as part of procedures for considering guarantee applications, the UKGSI will consider whether the PFI project demonstrates evidences that it will commence construction of the project within 52weeks of guarantee approval. This particular factor may however be undermined by the lengthy procedures for obtaining planning permits (HM Treasury, 2014). According to National Planning Act (2008), decisions on applications for development consent orders (DCOs) are in strict accordance with National Policy Statements (NPSs). However, NPSs passes through series of procedures with respect to public consultations and parliamentary enquiry, before government's formal approval. The entire cycle of obtaining planning commission's permit from the pre-application stage through to acceptance, pre-examination, examination, decision and post decision stage may take not less than one year and four months. Further evidence also indicates 
that, in a number of situations and for certain types of PFI infrastructures, sponsors may also be required to provide additional information with regards to compliance with the National Policy statements (NPSs). However, considering the amount of time invested in obtaining planning commission approval for PFI infrastructures (seeking to obtain UK guarantee), many applications have been aborted at this stage. Findings also show that many at times, project sponsors opt for a "Delay in Start-up Insurance", in order to boost chances of winning government guarantee approval. The National Audit Office in her recent report of 2015 has bemoaned the lengthy process of obtaining planning permit for projects seeking government guarantee, arguing that, such prolonged process is capable of frustrating successful implementation of the UK guarantee scheme.

\subsection{Conclusion}

The intervention of the UK government through the UK Guarantee Scheme for Infrastructures (UKGSI) became necessary upon the aftermath of the last global financial crisis, which badly affected the PFI market and threatened private sector finances for UK public infrastructures. This study investigated the perspectives of stakeholders in UK PFI/PPP industry with respect obtaining guarantee approval under the UKGSI. Issues such as critical factors for winning guarantee approval and divergent stakeholders' perspectives on guarantee criteria were explored. The study adopted a mixed methodological approach involving focus group discussions with PFI stakeholders (i.e. equity sponsors, lenders etc.) and postal questionnaire survey to ensure wider applicability of findings. After much explorative cum exploitative studies conducted, findings from the study revealed 26 important criteria influencing successful guarantee application. The significance index and raking of the criteria revealed five topmost criteria which includes: (i) project must be nationally or economically significant in nature (ii) project must be infrastructure in NIP-defined priority sectors (iii) compliance of project with European Commission's guidance on state guarantees (iv) strong financial credibility of project (v) project must be non-investment 
grade due to high construction risk. With the aid of factor analysis, a five factor-solution representing critical factors underlying the various criteria for winning the UK government guarantee approval were unravelled. These critical factors include; (i) project alignment with UK NIP policy in terms qualifying as infrastructure and falling within priority sectors (i.e. roads, rail, aviation, renewable energy etc.) (ii) Demonstration of project bankability and risk management (i.e. credit quality) (iii) Project's demonstration of value for money (VFM) (iv) demonstration of project's dependence on the guarantee scheme (v) certainty of obtaining planning commission's permits for projects. The study shows that, the five factor-solutions, if diligently incorporated in guarantee applications will enhance approval rate. Further evidences from the study also suggest differences of opinions among PFI industry stakeholders with respect to the appropriateness of a number of the criteria (i.e. value for money and project's contribution to economic growth). These diverse opinions put the private sector participants (i.e. equity sponsors, senior lenders and PFI/PPP contractors) and public sector employees on separate divide on issues. The study showed that the absence of objective testing indicators for certain guarantee criteria (VFM, measuring economic growth impact of project) have hindered project sponsors' understanding of how best to access the UK government guarantee scheme. The rigorous nature of the VFM assessment of the scheme has also been questioned with the public sector calling for project-level to guarantee-level VFM assessment. In this regard, policy makers must therefore address the divergent stakeholders' opinions, in order to create a win-win strategic framework with a bottom-up approach. Additionally, a robust engagement with industry stakeholders to foster clearer understanding of the guarantee scheme, transparent and objective evaluation of infrastructure project guarantee applications are also crucial for the public sector to consider. The national impact assessment of the scheme should therefore extend towards examining the total contribution of UKGSI to the entire segments of UK project finance and infrastructure industry as a whole. 
The outcome of this study has been limited to the criteria for accessing the UK Guarantee Scheme for Infrastructures, particularly with respect to PFI/PPP project financing. Currently, little is known regarding how the scheme evaluates the economic growth impact of a PFI/PPP project under the scheme. Further empirical research might also be required to examine the impact of the UKGSI on green field and brown field infrastructure investments in the UK. This study will no doubt be useful to policy makers, project sponsors, financiers and other industry stakeholders concerning reorganising the scheme as well as exploiting maximum benefits from such government policies in the near future.

\subsection{References:}

Abdel Aziz, A. M. (2007) A Survey of the Payment Mechanisms for Transportation DBFO Projects in British Columbia. Construction Management and Economics. 25(5), 529543.

Ahadzi, M., and Bowles, G. (2004) Public-Private Partnerships and Contract Negotiations: An Empirical Study. Construction Management and Economics. 22(9), 967-978.

Akintoye, A., Taylor, C., and Fitzgerald, E. (1998) Risk Analysis and Management of Private Finance Initiative Projects. Engineering, Construction and Architectural Management. 5(1), 9-21.

Akintoye, A., Hardcastle, C., Beck, M., Chinyio, E., \& Asenova, D. (2003) Achieving Best Value in Private Finance Initiative Project Procurement. Construction Management and Economics. 21(5), 461-470.

Alvesson, M., and Deetz, S. (2000) Doing Critical Management Research. Sage Publications Ltd, London.

Atmo, G., and Duffield, C. (2014) Improving Investment Sustainability for PPP Power Projects in Emerging Economies: Value for Money Framework. Built Environment Project and Asset Management. 4(4), 335-351.

Benito, B., Montesinos, V. and Bastida, F. (2008) An Example of Creative Accounting in Public Sector: The Private Financing of Infrastructures in Spain. Critical Perspectives on Accounting. 19(7), 963-986.

Bing, L., Akintoye, A., Edwards, P. J., and Hardcastle, C. (2005) The Allocation of Risk in PPP/PFI Construction Projects in the UK. International Journal of Project Management, 23(1), 25-35. 
Blaikie, N. (2000) Designing Social Research. Cornwall: Polity Press.

Carbonara, N., Costantino, N., and Pellegrino, R. (2014) Revenue Guarantee in Public-Private Partnerships: A Fair Risk Allocation Model. Construction Management and Economics. 32(4), 403-415.

Carrillo, P., Robinson, H., Foale, P., Anumba, C. and Bouchlaghem, D. (2008) Participation, Barriers, and Opportunities in PFI: The United Kingdom Experience. Journal of Management in Engineering. 24(3), 138-145.

Cheung, E., Chan, A. P., and Kajewski, S. (2009) Enhancing Value for Money in Public Private Partnership Projects: Findings from a Survey Conducted in Hong Kong and Australia Compared to Findings from Previous Research in the UK. Journal of Financial Management of Property and Construction. 14(1), 7-20.

Chioncel, N. E., Veen, R. V. D., Wildemeersch, D., and Jarvis, P. (2003) The validity and Reliability of Focus Groups as a Research Method in Adult Education. International Journal of Lifelong Education. 22(5), 495-517.

Chung, D., Hensher, D. A. and Rose, J. M. (2010) Toward the Betterment of Risk Allocation: Investigating Risk Perceptions of Australian Stakeholder Groups to Public-PrivatePartnership Toll-Road Projects. Research in Transportation Economics. 30(1), 43-58.

Crotty, J. (2009) Structural Causes of the Global Financial Crisis: A Critical Assessment of the 'New Financial Architecture'. Cambridge Journal of Economics. 33(4), 563-580.

Cooper, D. R., Schindler, P. S., and Sun, J. (2006) Business Research Methods (Vol. 9). [Online].New York: McGraw-hill.[Accessed 3rd April, 2015].

Connolly, C. and Wall, T. (2011) The Global Financial Crisis and UK PPPs. International Journal of Public Sector Management. 24(6), 533-542.

Cowling, M. (2010) The Role of Loan Guarantee Schemes in Alleviating Credit Rationing in the UK. Journal of Financial Stability. 6(1), 36-44.

Creswell, J. W. (2013) Research Design: Qualitative, Quantitative, and Mixed Methods Approaches.[Online]. Sage publications.[Accessed 4th Feb, 2015].

Cuttaree, V., and Mandri-Perrott, X. C. (2011) Public-Private Partnerships in Europe and Central Asia: Designing Crisis-Resilient Strategies and Bankable Projects. World Bank Publications.

Delmon, J., (2011); Public - Private Partnership Projects in Infrastructure: An Essential Guide for Policy Makers. New York: Cambridge university press.

Denzin, N. K., and Lincoln, Y. S. (Eds.) (2008) The Land Scape of Qualitative Research. Third Edition. USA: Sage Publication.

Demirag, I., Dubnick, M., and Khadaroo, M. I. (2004) A Framework for Examining Accountability and Value for Money in the UK's Private Finance Initiative. Journal of Corporate Citizenship. 2004(15), 63-76. 
Demirag, I., Khadaroo, I., Stapleton, P., and Stevenson, C., (2011) Risks and the Financing of PPP: Perspectives from the Financiers. The British Accounting Review. 43 (2011) 294310.

Demirag, I., Khadaroo, I., and Stapleton, P. (2015) A Changing Market for PFI Financing: Evidence from the Financiers. In Accounting Forum (Vol. 39, No. 3, pp. 188-200). Elsevier.

Dailami, M. and Klein, M. (1997) Government Support to Private Infrastructure Projects in Emerging Markets. Dealing with Public Risk in Private Infrastructure, 17322, 21-42.

Drew, M. E. (2010) The Future of Financial Regulation: Lessons from the Global Financial Crisis. Griffith Law Review, 19(1), 1-5.

Downward, P., \& Mearman, A. (2007) Retroduction as Mixed-Methods Triangulation in Economic Research: Re-orienting Rconomics into Social Science. Cambridge Journal of Economics, 31(1), 77-99.

EPEC, (2013). Market update: Review of the European PPP market in 2012 Available at http://www.eib.org/epec/resources/epec (accessed May 2014).

Farrar, J. H. and Mayes, D. G. (Eds.). (2013) Globalization, the Global Financial Crisis and the State. Edward Elgar Publishing.

Farrell, L. M. (2003) Principal-Agency Risk in Project Finance. International Journal of Project Management. 21(8), 547-561.

Field, A. (2005). Discovering Statistics using SPSS, 2nd Ed., Sage Publications, London.

Garrett, G. (2010) G2 in G20: China, the United States and the World after the Global Financial Crisis. Global Policy. 1(1), 29-39.

Grimsey, D., and Lewis, M., (2002) "Evaluating the Risks on Public Private Partnerships for Infrastructure Projects", International Journal of Project Management. Vol. 20, pp 107118.

Grimsey, D., and Lewis, M., (2004) Public Private Partnerships: The Worldwide Revolution in Infrastructure Provision and Project Finance. Cheltenham: Edward Elgar.

Gropp, R., Gruendl, C. and Guettler, A. (2014) The Impact of Public Guarantees on Bank RiskTaking: Evidence from a Natural Experiment. Review of Finance. 18(2), 457-488.

Hampl, N., Ludeke-Freund, F., Flink, C., Olbert, S., and Ade, V., (2011) "The Myth of Bankability - Definition and Management in the context of Photovoltaic Project Financing in Germany". (Online) Available at: https://www.alexandria.unisg.ch/export/DL/210237.pdf. [Accessed: 14th Feb, 2014].

Haran, M., McCord, M., Hutchison, N., McGreal, S., Adair, A., Berry, J. and Kashyap, A. (2013) Financial Structure of PPPs Deals Post-GFC: An International Perspective. Journal of Financial Management of Property and Construction. 18(2), 184-203. 
Hite, G. and Warga, A. (1997) The Effect of Bond-Rating Changes on Bond Price Performance. Financial Analysts Journal. 53(3), 35-51.

HM Treasury, (2012) A New Approach to Public Private Partnerships. London: HMSO.

HM Treasury, (2014) Private Finance Initiative Projects: Summary Data. London: HMSO.

HM Treasury, (2014) Infrastructure Plan. pp108, 10926.

HM Treasury, (2013) National Infrastructure Plan. (Online) Available at [www.nationalarchives.gov.uk/doc/open-government-licence.].[Accessed on $12^{\text {th }}$ July, 2015].

Hoffman, S.L., (2008) The law and Business of International Project Finance, 3rd edition. New York: Cambridge University press.

Hodge, G. A. and Greve, C. (2007) Public-Private Partnerships: An International Performance Review. Public Administration Review. 67(3), 545-558.

Johnson, P., and Duberley, J. (2000) Understanding Management Research: An Introduction to Epistemology. Sage Publications Ltd, London.

Johnson, R. B. and Onwuegbuzie, A. J. (2004) Mixed Methods Research: A Research Paradigm Whose Time has come. Educational Researcher. 33(7), 14-26.

Johal, S., Moran, M., and Williams, K. (2012) The Future has been Postponed: The Great Financial Crisis and British Politics. British Politics. 7(1), 69-81.

Ke, Y., Wang, S., Chan, A. P. and Lam, P. T. (2010) Preferred Risk Allocation in China's PublicPrivate Partnership (PPP) Projects. International Journal of Project Management. 28(5), 482-492.

Kumaraswamy, M. M. and Zhang, X. Q. (2001) Governmental Role in BOT-led Infrastructure Development. International Journal of Project Management, 19(4), 195-205.

Kwak, Y. H., Chih, Y. and Ibbs, C. W. (2009) Towards a Comprehensive Understanding of Public Private Partnerships for Infrastructure Development. California Management Review. 51(2), 51-78.

Li, B., Akintoye, A., Edwards, P. J., and Hardcastle, C. (2005) Critical Success Factors for PPP/PFI Projects in the UK Construction Industry. Construction Management and Economics. 23(5), 459-471.

Lincoln, Y. S. and Denzin, N. K. (1994) The Fifth Moment. Handbook of Qualitative Research. $1,575-586$.

Marshall, M. N. (1996). Sampling for Qualitative Research. Family Practice. 13(6), 522-526.

Meng, X. and Mckevitt N., (2011) "Improving the Bankability of a PFI Financing Application". The Journal of Structured Finance. Vol.17 (3), pp 78-87. 
Meredith, W. (1993) Measurement Invariance, Factor Analysis and Factorial Invariance. Psychometrika. 58(4), 525-543.

Mills, S., (2010) “The Mechanics of Project Finance”. Institute for International Research (IIR) Limited, U.K.

National Audit Office, (2012). Equity Investments in Privately Financed Projects. HC1792. London: HMSO.

National Audit Office, (2015) UK Guarantees scheme for infrastructure, p6.

National Infrastructure Plan (2011) National Infrastructure Plan. (Online) Available at https://www.gov.uk/government/uploads/system/uploads/attachment data/file/188337 Inip 2011.pdf. [Accessed on $18^{\text {th }}$ April, 2015].

National Planning Act, (2008) Nationally Significant Infrastructure Projects. Available at https://www.gov.uk/government/uploads/system/uploads/attachment_data/file/7769/a pplicationformguidance.pdf. [Accessed on 15th May, 2015].

Neuman, W. L., and Neuman, W. L. (2006) Social Research Methods: Qualitative and Quantitative Approaches. [Online]. Publisher: Pearson Education. Pages: 599 [Accessed on 7th Feb, 2015].

Nunnaly, J. (1978) Psychometric Theory. New York: McGraw-Hill.

Olusola Babatunde, S., Opawole, A. and Emmanuel Akinsiku, O. (2012) Critical Success Factors in Public-Private Partnership (PPP) on Infrastructure Delivery in Nigeria. Journal of Facilities Management. 10(3), 212-225.

Oyedele, L., (2013) “Avoiding Performance Failure Payment Deductions in PFI/PPP Projects:

Model of Critical Success Factors". Journal of Performance of Constructed Facilities.

Volume 27, Issue 3 (June 2013), pp. 283-294..

Rigobon, R. (2002) The Curse of Non-Investment Grade Countries. Journal of Development Economics. 69(2), 423-449.

Robinson, H. S. and Scott, J. (2009). Service Delivery and Performance Monitoring in PFI/PPP Projects. Construction Management and Economics. 27(2), 181-197.

Spillane, J.P., Oyedele, L.O., and von Meding, J. (2012) Confined Site Construction. Journal of Engineering, Design and Technology. 10(3), pp. 397-420. doi:10.1108/17260531211274747.

Tam, C.M., Deng, Z.M., Zeng, S.X., and Ho, C.S. (2000) Quest for Continuous Quality Improvement for Public Housing Construction in Hong Kong, Construction Management and Economics. 18(4), pp. 437-446. doi:10.1080/01446190050024851.

Thorhallsson, B. and Kirby, P. (2012) Financial Crises in Iceland and Ireland: Does European Union and Euro Membership matter. Journal of Common Market Studies. 50(5), 801818. 
Tiong, R. L. (1995) Risks and Guarantees in BOT Tender. Journal of Construction Engineering and Management.

Toms, S., Beck, M. and Asenova, D. (2011).Accounting, Regulation and Profitability: The Case of PFI Hospital Refinancing. Critical Perspectives on Accounting. 22, 668-681.

Tucker, L. R. and Lewis, C. (1973) A Reliability Coefficient for Maximum Likelihood Factor Analysis. Psychometrika, 38(1), 1-10.

Visconti, R. M. (2013) Evaluating a Project Finance SPV: Combining Operating Leverage with Debt Service, Shadow Dividends and Discounted Cash Flows. Management, 1(1), 920.

Wang, S. Q., Tiong, R. L., Ting, S. K. and Ashley, D. (2000) Evaluation and Management of Political Risks in China's BOT Projects. Journal of Construction Engineering and Management. 126(3), 242-250

Webb, E. J., D.T. Campbell, R. D. Schwartz and L. Sechrest (1966) Unobtrusive Measures: NonReactive Research in Social Sciences.[Online]. Chicago Ill: Rand McNally.[Accessed on 5th March, 2015].

Wibowo, A. and Kochendoerfer, B. (2010) Selecting BOT/PPP Infrastructure Projects for Government Guarantee Portfolio under Conditions of Budget and Risk in the Indonesian Context. Journal of Construction Engineering and Management. 137(7), 512-522.

Wynne, A. (2015) Government-Backed Infrastructure Schemes Failed To Meet UK Guarantees Criteria, Says Watchdog. [Online] Available at http://www.nce.co.uk/news/governmentbacked-infrastructure-schemes-failed-to-meet-uk-guarantees-criteria-sayswatchdog/8677651.article. [Accessed: $12^{\text {th }}$ Feb, 2015].

Yang, Y., Hou, Y. and Wang, Y. (2013) On the Development of Public-Private Partnerships in Transitional Economies: An Explanatory Framework. Public Administration Review. 73(2), 301-310.

Yescombe, E. R. (2013) Principles of Project Finance. Academic Press.

Zhang, X. (2005) Paving the Way for Public-Private Partnerships in Infrastructure Development. Journal of Construction Engineering and Management. 131(1), 71-80. 


\section{$\underline{\text { Response to Reviewers' Comments and Feedbacks }}$}

\begin{tabular}{|l|l|l|}
\hline S/N & \multicolumn{2}{|c|}{ Responses } \\
\hline & Reviewer 1: & \\
\hline $\mathbf{1}$ & $\begin{array}{l}\text { "The results presented in Table 4 could be } \\
\text { split into 3-4 Tables to put the findings } \\
\text { into a much more clear perspective. It } \\
\text { appears lumpy and cumbersome as it is." }\end{array}$ & $\begin{array}{l}\text { Thanks a lot for the feedback. This has } \\
\text { been adequately addressed in the } \\
\text { manuscript. Kindly see Tables 4 \&5 on } \\
\text { Pages 19 \& 20 respectively for correction. }\end{array}$ \\
\hline $\mathbf{2}$ & $\begin{array}{l}\text { "However, there are still some minor } \\
\text { editorial errors. For example, line 311 on } \\
\text { Pg 16, dada should be data". }\end{array}$ & $\begin{array}{l}\text { Much appreciation for the feedback. The } \\
\text { entire manuscript has been proof read for } \\
\text { typo errors. However see Page 15, line 6-8 } \\
\text { for the correction requested. }\end{array}$ \\
\hline $\mathbf{1}$ & $\begin{array}{l}\text { "Toviewer 2: } \\
\text { diagrammatically show the factors } \\
\text { identified as critical". }\end{array}$ & $\begin{array}{l}\text { Kindly see Page 17, line 354 for Scree Plot } \\
\text { of the Factor Analysis conducted in the } \\
\text { study. }\end{array}$ \\
\hline $\mathbf{2}$ & $\begin{array}{l}\text { "A scree plot would have helped to } \\
\text { further highlight the critical factors that } \\
\text { have been identified." }\end{array}$ & $\begin{array}{l}\text { Please see Page 17, line 354 for } \\
\text { correction. }\end{array}$ \\
\hline
\end{tabular}

